\title{
Light Control Using Human Body Temperature Based on Arduino Uno and PIR (Passive Infrared Receiver) Sensor
}

\author{
Reza Perkasa ${ }^{1}$, Refni Wahyuni ${ }^{2}$, Rika Melyanti ${ }^{3}$, Herianto ${ }^{4}$, Yuda Irawan ${ }^{5 *}$ \\ 1,2 Department of Computer Science, STMIK Hang Tuah Pekanbaru, Pekanbaru, Indonesia \\ 3, 4,5 Department of Information System, STMIK Hang Tuah Pekanbaru, Pekanbaru, Indonesia \\ Email: ${ }^{1}$ rezaperkasa13@gmail.com, ${ }^{2}$ refniabid@ gmail.com, ${ }^{3}$ alulalfiyah@ gmail.com, ${ }^{4}$ herianto.sy@ gmail.com, \\ ${ }^{5}$ yudairawan89@gmail.com \\ *Corresponding Author
}

\begin{abstract}
This study aims to implement the PIR sensor, Arduino UNO and 2 channel relay Module to automatically turn on the lights in the classroom at the STMIK Hang Tuah Pekanbaru campus, where the classes at the Hang Tuah Pekanbaru STMIK campus still use manual switches as controller's lights on. Therefore, a device is designed that can control the lights by using movements detected by the PIR sensor and processed using a computer. This system functions to turn on the lights automatically when someone enters the classroom and turn off the lights automatically when no one is in the class. The hardware used is Arduino Uno microcontroller, PIR motion sensor, 2 channel relay module, and 1.5-volt flashlight. The software for making programs is Arduino IDE where the programming language used is the $\mathrm{C}$ programming language. The test results show that the PIR sensor can detect the movement of people entering or leaving a room.
\end{abstract}

Keywords: Arduino Uno, Light Control, PIR Sensor, Body Temperature

\section{INTRODUCTION}

In life we need a light source in our daily activities. If during the day we get the light source from the sun, then at night we get it from the lights was studied by zanchi [1]. A lamp is an electronic device that converts electrical energy into light was studied by bandopadhyay [2]. This electronic device is needed by many people, especially at night. To turn on the light, we have to turn it on and off manually was studied by zhang [3].

The rapid development of the times at this time, especially in the field of hardware (Hardware) makes it easier for humans to complete their daily activities was studied by irawan [4]. Various electronic devices can be connected and controlled using a computer with the help of a driver that connects the electronic device to the computer, for example: Controlling automatic lights using Arduino Uno and motion sensors was studied by you [5].

This electronic device works by using a switch to activate or deactivate it was studied by fatmawati [6]. The problem that often occurs at STMIK Hang Tuah Pekanbaru is that the light control system at STMIK Hang Tuah Pekanbaru still uses a switch was studied by muhardi [7].
Turning the lights on and off is done manually, so it is less effective in controlling the lights, because at STMIK Hang Tuah Pekanbaru, after night lectures was studied by power [8], they often don't turn off the lights before leaving the room, at STMIK Hangtuah Pekanbaru to control and turn off the class lights is the responsibility of cleaning service for class implementation morning was studied by chen [9]. While controlling the lights for the night class is the responsibility of the night guard was studied by irawan [10], but the security guard at night is only one person, and in turning off the lights in the room the security guard has to leave the security post, and that too makes the security post not guarded was studied by ahmed [11], so from it is often the lights that are left on until daylight was studied by saad [12]. So that there was an increase in payments on electricity bills was studied by kobra [13]. To overcome this, it is necessary to develop an intelligent system that can control lights without having to use a switch was studied by irawan [14].

An intelligent system is a system that can adopt a small part of the level of human intelligence to interact with the external state of a system was studied by kobra [13]. A small part of the level of intelligence includes: the ability to be trained, recall conditions that have been experienced, process data to provide the right action according to what has been taught, and the ability to absorb the expertise of an expert through commands written in a particular programming language was studied by lenardo [15].

By combining lights and computers, we can produce an intelligent light control system that is controlled using human body temperature was studied by Umemura [16]. Passive Infrared Receiver sensor (PIR) is an electronic sensor that measures infrared light emitting from objects around it was studied by tang [17]. The working principle of this smart system is that the PIR sensor will detect the presence of people through body temperature and human movement in one room was studied by wahyuni [18]. And the computer will respond to the presence of people to turn on and turn off the lights like a switch was studied by Thomas [19]. 
Therefore, a device is designed that can control the lights by using movements detected by the PIR sensor and processed using a computer was studied by lestari [20].

\section{METHODS}

In this stage the researcher uses the prototype method, because this method is a method that is widely used by software developers was studied by wahyuni [21]. The essence of this method is the work of a model development into a final system. Following are the Stages of Prototype Model Development:

\section{A. Collection of Needs}

Collection of Requirements is the stage where the client and developer jointly define the software and identify needs and systems that are created in consultation with the Pekanbaru City Environmental and Sanitation Office was studied by Irawan [22].

\section{B. Prototype Design Process}

At this stage of the design process the authors plan and design the design before carrying out the tool-making process was studied by chang [23].

\section{Building Prototype}

In this stage the writer builds a prototype while designing a temporary design that focuses on making tools was studied by kun [24].

\section{Prototype Evaluation}

In the Prototyping Evaluation Phase, the results of the software design will be realized to the cleaning officers of the Pekanbaru City Environment and Sanitation Service, whether the prototyping that is built is in accordance with the wishes and needs of the janitor or not. If it does not match, the prototyping will be revised by repeating the previous steps. But if it is appropriate, then the next step will be carried out.

\section{IMPLEMENTATION}

\section{A. Design hardware (hardware}

It is a design or series of tools used to build light control using human body temperature based on Arduino uno and PIR (Passive Infrared Receiver) sensors.

1) Arduino Uno Microcontroller Series with 2 Channel Relay Module 2 Channel Relay Module with Arduino Uno Microcontroller serves as a connecting medium for Arduino Uno Lights and Microcontroller so that the electric current to the lights can be controlled (Figure 1).

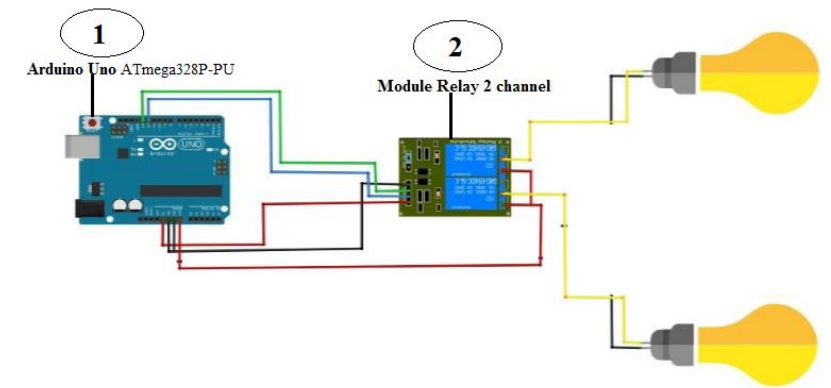

Fig. 1. Arduino Uno circuit with 2 channel Relay Module.
2) Arduino Uno Microcontroller Circuit with PIR (Passive Infrared Receiver) Sensor

The series of PIR (Passive Infrared Receiver) sensors with an Arduino Uno microcontroller is used to adjust the electric current to the PIR (Passive Infrared Receiver) sensor. This circuit is designed according to the Arduino microcontroller program, where there is a control signal from the Arduino microcontroller.

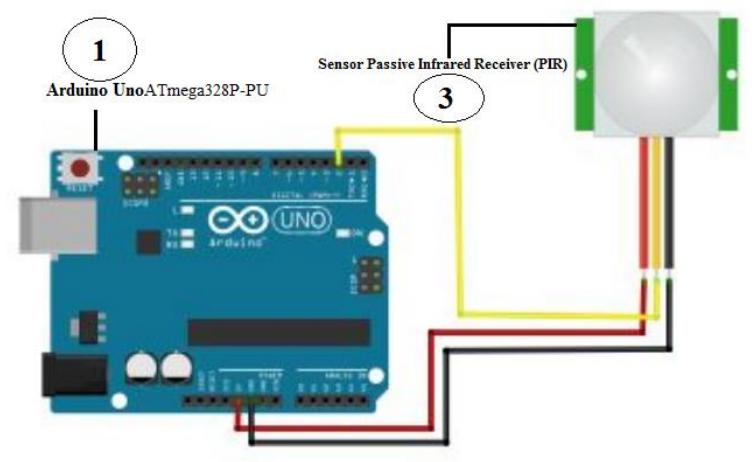

Fig. 2. Arduino Uno circuit and PIR (Passive Infrared Receiver) Sensor.

Implementation is one of the stages in system development, where this stage is the stage of putting the light control system on the STMIK Hang Tuah Pekanbaru campus so that it is ready to operate and can be seen as an effort to realize the system that has been designed. Simulation of lighting control at the STMIK Hang Tuah Pekanbaru is shown in Figure 3.

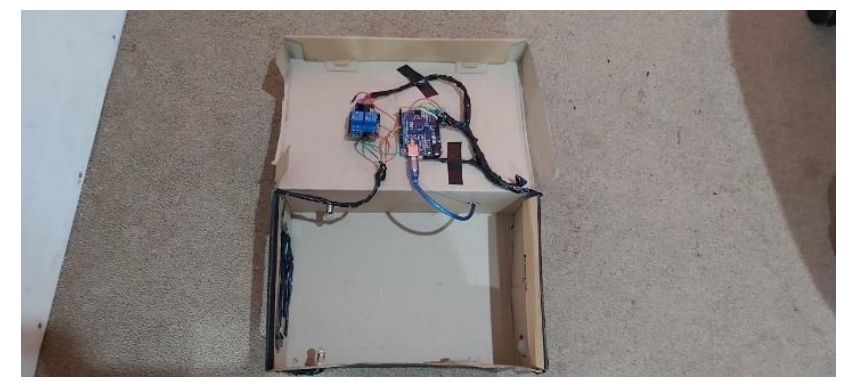

Fig. 3. Simulation of lighting control at the STMIK Hang Tuah Pekanbaru

\section{B. System Testing}

Testing the system of light control using human body temperature based on Arduino UNO and PIR (Passive Infrared Receiver) sensors can be done with the following steps:

1. Turn on the lamp control simulation first using Powerbank.

2. After that the light control system uses human body temperature based on Arduino UNO and the PIR (Passive Infrared Receiver) sensor will turn on like the supporting devices, namely the Arduino uno, 2 channel Relay Module, and Lights (Figure 4). 


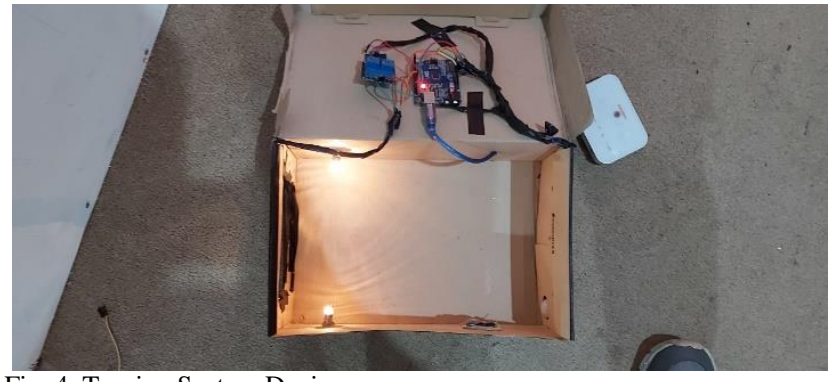

Fig. 4. Turning System Devices

3. Let the simulation load for approximately 30 seconds.

4. After 30 seconds the lamp will turn off (Figure 5).

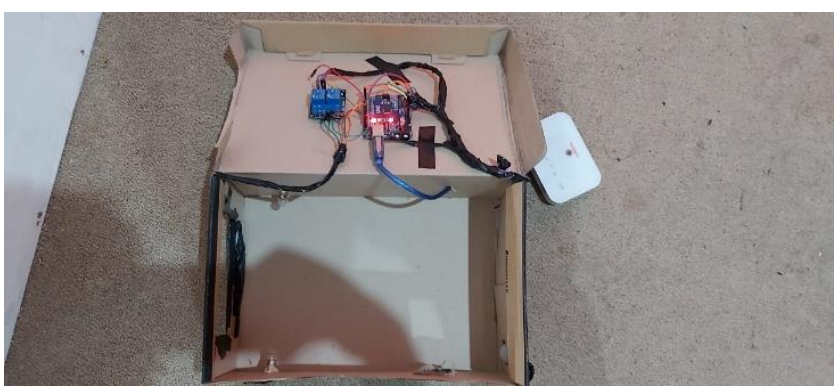

Fig. 5. Simulation device after being idle for 30 seconds

5. The lamp control simulation is ready for use (Figure 6).

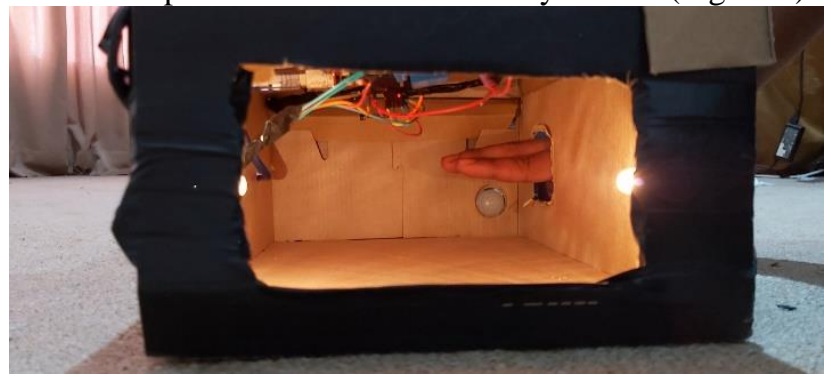

Fig. 6. Simulation Tools used

TABLE 1. PIR (PASsive INFRAREd ReCEIVER) SENSOR TESTing

\begin{tabular}{|c|c|c|c|}
\hline Trial & Type of Testing & $\begin{array}{c}\text { Which is } \\
\text { expected }\end{array}$ & Result \\
\hline 1 & $\begin{array}{c}\text { Hands put into the simulation } \\
\text { box }\end{array}$ & The lights are on & Success \\
\hline 2 & Hands out of the simulation box & Lights off & Success \\
\hline
\end{tabular}

\section{CONCLUSION}

Based on the results of the analysis, design and implementation that has been done. Then several conclusions can be drawn including the following: Control of Lights Using Human Body Temperature Based on Arduino UNO and PIR (Passive Infrared Receiver) Sensor is effectively used to control room lights at STMIK Hang Tuah Pekanbaru. Light Control Using Human Body Temperature Based on Arduino UNO and PIR (Passive Infrared Receiver) Sensor can help the performance of campus security guards at STMIK Hang Tuah Pekanbaru. Control of lights using human body temperature based on Arduino UNO and PIR (Passive Infrared Receiver) sensors can save on electricity bills on the campus of STMIK Hang Tuah Pekanbaru.

\section{REFERENCES}

[1] M. G. Zanchi, R. Venook, J. M. Pauly and G. C. Scott, "An Optically Coupled System for Quantitative Monitoring of MRIInduced RF Currents Into Long Conductors," in IEEE Transactions on Medical Imaging, vol. 29, no. 1, pp. 169-178, Jan. 2010, doi: 10.1109/TMI.2009.2031558.

[2] S. Bandopadhyay, A. Kole and P. Das, "Review and studies on the effect of spectral composition of LED based lighting system over its scotopic-photopic ratio," 2016 International Conference on Intelligent Control Power and Instrumentation (ICICPI), Kolkata, 2016, pp. 221-225, doi: 10.1109/ICICPI.2016.7859706.

[3] Y. Zhang, Z. Chen, W. Chen and H. Li, "Unobtrusive and Continuous BCG-Based Human Identification Using a Microbend Fiber Sensor," in IEEE Access, vol. 7, pp. 72518-72527, 2019, doi: 10.1109/ACCESS.2019.2919407.

[4] Irawan, Y., Fernando, Y., \& Wahyuni, R. Detecting Heart Rate Using Pulse Sensor As Alternative Knowing Heart Condition. Journal of Applied Engineering and Technological Science (JAETS), 2019, 1(1), pp 30-42.

[5] W. You and H. Ge, "Design and Implementation of Modbus Protocol for Intelligent Building Security," 2019 IEEE 19th International Conference on Communication Technology (ICCT), Xi'an, China, 2019, pp. 420-423, doi: 10.1109/ICCT46805.2019.8946996.

[6] Fatmawati, Kiki, et al. Rancang Bangun Tempat Sampah Pintar Menggunakan Sensor Jarak Berbasis Mikrokontroler Arduino. Riau Journal Of Computer Science, 2020, 6.2: 124-134.

[7] Muhardi, Muhardi, et al. "Design Of Web Based LMS (Learning Management System) in SMAN 1 Kampar Kiri Hilir." Journal of Applied Engineering and Technological Science (JAETS) 1.2 (2020): 70-76.

[8] H. M. Power, "Some limits of the human body. Joe Bloggs under control," in Electronics and Power, vol. 23, no. 3, pp. 229-234, March 1977, doi: 10.1049/ep.1977.0125.

[9] K. Chen, H. Chan, Y. Hung and S. Shieh, "A Smart LED Lighting with Multiple Dimming and Temperature Automatic Protection Capabilities," 2016 International Symposium on Computer, Consumer and Control (IS3C), Xi'an, 2016, pp. 614-617, doi: 10.1109/IS3C.2016.158.

[10] Irawan, Yuda. "Implementation Of Data Mining For Determining Majors Using K-Means Algorithm In Students Of SMA Negeri 1 Pangkalan Kerinci." Journal of Applied Engineering and Technological Science (JAETS) 1.1 (2019): 17-29.

[11] I. Ahmed, S. Halder, A. Bykov, A. Popov, I. V. Meglinski and M. Katz, "In-Body Communications Exploiting Light: A Proof-ofConcept Study Using Ex Vivo Tissue Samples," in IEEE Access, vol. $\quad 8, \quad$ pp. 190378-190389, 2020, doi: 10.1109/ACCESS.2020.3031574

[12] N. M. Saad et al., "Wireless PIR \& D6T thermal sensor based lighting \& air-conditioning control device for building," 4th IET Clean Energy and Technology Conference (CEAT 2016), Kuala Lumpur, 2016, pp. 1-8, doi: 10.1049/cp.2016.1283.

[13] K. T. Kobra, A. Debnath and P. P. Rawshan, "Temperature and Power Control of Water Geyser Using Learning Technique," 2018 3rd International Conference for Convergence in Technology (I2CT), Pune, 2018, pp. 1-6, doi: 10.1109/I2CT.2018.8529715.

[14] P. Czamul, "Design of a distributed system using mobile devices and workflow management for measurement and control of a smart home and health," 2013 6th International Conference on Human System Interactions (HSI), Sopot, 2013, pp. 184-192, doi: 10.1109/HSI.2013.6577821.

[15] Lenardo, Gilang Citra, et al. Pemanfaatan Bot Telegram sebagai Media Informasi Akademik di STMIK Hang Tuah Pekanbaru. JTIM: Jurnal Teknologi Informasi dan Multimedia, 2020, 1.4: 351-357.

[16] G. S. Umemura, C. L. Noriega, D. F. Soares and A. Forner-Cordero, "Biomechanical procedure to assess sleep restriction on motor control and learning," 2017 39th Annual International Conference of the IEEE Engineering in Medicine and Biology Society (EMBC), Seogwipo, 2017, pp. 1397-1400, doi: 10.1109/EMBC.2017.8037094.

[17] F. Tang et al., "A Low Power and Fast Tracking Light-to-Frequency Converter With Adaptive Power Scaling for Blood SpO\$_\$ Sensing," in IEEE Transactions on Biomedical Circuits and Systems, vol. 13, no. 1, pp. 26-37, Feb. 2019, doi: 10.1109/TBCAS.2018.2889745. 
[18] Wahyuni, Refni; Irawan, Yuda. Web-Based Employee Performance Assessment System in PT. Wifiku Indonesia. Journal of Applied Engineering and Technological Science (JAETS), 2020, 1.2: 60-69.

[19] S. S. Thomas, A. Saraswat, A. Shashwat and V. Bharti, "Sensing heart beat and body temperature digitally using Arduino," 2016 International Conference on Signal Processing, Communication, Power and Embedded System (SCOPES), Paralakhemundi, 2016, pp. 1721-1724, doi: 10.1109/SCOPES.2016.7955737.

[20] Lestari, Uning; Fatkhiyah, Erfanti; Prakoso, Andung Febi. Application Of Home Light Control System Using Arduino With Mobile Based Wifi Media. Ijiscs (International Journal of Information System And Computer Science), 2019, 2.2: 67-75.

[21] Wahyuni, Refni; Rickyta, Aditya ; Rahmalisa, Uci ; Irawan, Yuda. Home Security Alarm Using Wemos D1 And HC-SR501 Sensor Based Telegram Notification. Journal of Robotics and Control (JRC), 2020, 2.3: 200-204.
[22] Irawan, Yuda. Aplikasi Pemetaan Data Konsumen Aktif Menggunakan Google Maps Pada Pt. Big Tv Pekanbaru. Jurnal Ilmu Komputer, 2019, 8.1: 107-112.

[23] Y. Chang, K. Huang, C. Yang and H. Tsai, "Evaluation of absorbed light dose in human skin tissue during Light Therapy by 630nm LED light," 2015 IEEE 12th International Conference on Networking, Sensing and Control, Taipei, 2015, pp. 394-398, doi: 10.1109/ICNSC.2015.7116069.

[24] Kun-Ying Lin, Ming-Wei Hsu and Shi-Rung Liou, "Bicycle management systems in anti-theft, certification, and race by using RFID," Proceedings of 2011 Cross Strait Quad-Regional Radio Science and Wireless Technology Conference, Harbin, 2011, pp. 1054-1057, doi: 10.1109/CSQRWC.2011.6037138. 